\title{
Quantitative real-time PCR detection of a harmful unarmoured dinoflagellate, Karlodinium australe (Dinophyceae)
}

\author{
Nyuk Fong Kon, ${ }^{1}$ Winnie L. S. Lau, ${ }^{2}$ Kieng Soon Hii, ${ }^{1,2}$ Ing Kuo Law, ${ }^{2}$ Sing Tung Teng, ${ }^{3}$ Hong Chang Lim, ${ }^{4}$ Kazuya Takahashi, ${ }^{5}$ \\ Haifeng Gu, ${ }^{6}$ Po Teen Lim $^{2 *}$ and Chui Pin Leaw (D) ${ }^{2 *}$ \\ ${ }^{1}$ Institute of Biodiversity and Environmental Conservation, Universiti Malaysia Sarawak, Kota Samarahan, Malaysia, \\ ${ }^{2}$ Institute of Ocean and Earth Sciences, University of Malaya, Bachok, Malaysia, ${ }^{3}$ Faculty of Resource Science and \\ Technology, Universiti Malaysia Sarawak, Kota Samarahan, Malaysia, ${ }^{4}$ Faculty of Applied Sciences and Computing, Tunku \\ Abdul Rahman University College, Segamat, Malaysia, ${ }^{5}$ Asian Natural Environmental Science Center, The University of \\ Tokyo, Tokyo, Japan and ${ }^{6}$ Third Oceanography Institute, Xiamen, China
}

\begin{abstract}
SUMMARY
We investigated a harmful algal bloom (HAB) associated with the massive fish kills in Johor Strait, Malaysia, which recurred a year after the first incident in 2014. This incident has urged for the need to have a rapid and precise method in HAB monitoring. In this study, we develop a SYBR green-based realtime PCR (qPCR) to detect the culpable dinoflagellate species, Karlodinium australe. Species-specific qPCR primers were designed in the gene region of the second internal transcribed spacer of the ribosomal RNA gene ( $r D N A)$. The species specificity of the primers designed was evaluated by screening on the non-target species (Karlodinium veneficum, Takayama spp., and Karenia spp.) and no cross-detection was observed. The extractable gene copies per cell of $K$. australe determined in this study were $19998 \pm 505(P<0.0001)$. Estimation of cell densities by $\mathrm{q} P C R$ in the experimental spiked samples showed high correlation with data determined microscopically $\left(R^{2}=0.93\right)$. Using the $\mathrm{q} P C R$ assay developed in this study, we successfully detected the 2015 bloom species as $K$. australe. Single-cell PCR and rDNA sequencing from the field samples further confirmed the finding. With the sensitivity as low as five cells, the qPCR assay developed in this study could effectively and rapidly detect cells of $K$. australe in the environmental samples for monitoring purpose.
\end{abstract}

Key words: fish kill, Malaysia, ribosomal RNA gene, second internal transcribed spacer.

\section{INTRODUCTION}

Rapidly expanding aquaculture activities and industrialization in coastal regions may have contributed to an increase in nutrient loadings, and resulted in localized eutrophication. Together with favorable physical conditions, this will promote rapid growth of phytoplankton, and algal bloom is likely to occur (Hall et al. 2008). Some of these algal blooms are known to cause harm by producing biotoxins that can intoxicate humans or kill marine organisms. Thus, rapid harmful algal detection tools are needed for regular monitoring and early prediction of these harmful algal blooms (HABs).
Johor Strait, located between the southern Peninsular Malaysia and Singapore, is an important site of mariculture industries for both countries. Fish farms and the number of cages in the Strait have been reported to have increased compared to a decade ago, with the production of milkfish (Chanos chanos) at US $\$ 6755 /$ metric tons for Singapore, the second highest fish mariculture production among Southeast Asian countries in 2014 (SEAFDEC 2017). This is accompanied by the increasingly reported cases of HABs in the strait. The first HAB event was recorded in 2002, where a massive bloom of Prorocentrum minimum (Pavillard) Schiller occurred in the strait (Usup et al. 2003). In a field survey along the strait, Tan et al. (2013) encountered a low cell abundance of Karlodinium species, identified as $K$. veneficum (Ballantine) Larsen at that time based on the morphological observations. The presence of Karlodinium species in the strait has gained serious attention as some species from the genus are known to kill fish (e.g. Deeds et al. 2002; Kempton et al. 2002). The genus Karlodinium was raised from polyphyletic Gymnodinium sensu lato after several taxonomic amendments based on the morphological ultrastructure features, the composition of photosynthetic pigments and the nuclear-encoded large subunit ribosomal RNA gene (LSU rDNA) sequences (Daugbjerg et al. 2000; Bergholtz et al. 2005). Before 2008, the genus comprised of four species: K. armiger Bergholtz, Daugbjerg \& Moestrup, K. australe de Salas, Bolch \& Hallegraeff, $K$. veneficum and $K$. vitiligo (Ballantine) Larsen (Bergholtz et al. 2005; de Salas et al. 2005). Meanwhile, K. micrum has been synonymized as K. veneficum (Bergholtz et al. 2005). The number of described Karlodinium species has grown to 11 , with the addition of species: K. antarcticum de Sales, K. ballantinum de Salas, $K$. conicum de Salas, $K$. corrugatum de Salas, K. decipiens de Salas \& Laza-Martinez (de Salas et al. 2008), K. corsicum (Paulmier) Siano \& Zingone, and K. gentienii Nézan, Chomérat \& Siano (Siano et al. 2009). Species of Karlodinium have a broad global distribution and have been reported from both the Pacific

\footnotetext{
* To whom correspondence should be addressed. Email:cpleaw@um.edu.my; ptlim@um.edu.my Communicating Editor: Mitsunori Iwataki Received 15 August 2016; accepted 12 April 2017.
} 